\author{
JURNAL PENJAMINAN MUTU \\ LEMBAGA PENJAMINAN MUTU \\ INSTITUT HINDU DHARMA NEGERI \\ DENPASAR
}

Volume 5 Nomor 2 Agustus 2019

ISSN : 2407-912X (Cetak)

ISSN : 2548-3110 (Online)

http://ejournal.ihdn.ac.id/index.php/JPM

\title{
THE USE OF MOODLE-BASED E-LEARNING IN EVALUATING STUDENTS' LEARNING
}

\author{
Oleh \\ I Gusti Ngurah Triyana, Ni Ketut Sri Ratmini, I Wayan Mandra*, \\ Ni Wayan Ruscitadewi \\ Institut Hindu Dharma Negeri Denpasar, Bali, Indonesia \\ *mandrafda@ihdn.ac.id
}

diterima 01 Juli 2019, direvisi 30 Juli 2019, diterbitkan 31 Agustus 2019

\begin{abstract}
Education is a very important thing in Indonesia. It is the main concern of this nation, because education will determine the direction of progress of a nation. Education is a conscious and planned guidance from educators on the physical and spiritual development of students towards the formation of humans who have the main knowledge and personality. In the process of education, science must be owned by educators and taught to students so that it will be able to be absorbed and developed more optimally. To find out the success or failure of the guidance received by students, it is necessary to conduct an evaluation to find out the development of knowledge taught by the teacher. In teaching, successful evaluation determines the steps that can be taken by students and teachers in knowing the development and improving the quality of education in the future. Currently technological advances have a direct impact on the world of education where e-learning-based teaching becomes an option that can support and teach students in developing materials and abilities in the field of technology. Moodle is one of the evaluation programs that use technological progress to facilitate and teach students to get to know more about technological progress.
\end{abstract}

\section{Keywords: Moodle-Based E-Learning; Evaluating Students' Learning}

\section{Introduction}

Education is a process to construct a good human by the government with the community. Education has a complex responsibility for the burden given by the teacher to students continuously. Education organized by the government with the community is expected to be able to change the knowledge of each student through the theories he learns. The education process provided by teachers to students is expected to be able to increase knowledge according to the standards of competence and basic 
competencies that have been implemented by the National Education Standard.

This adjustment is intended to follow and integrate learning activities comprehensively so that later students can grow and develop into intelligent adults and have religious values as well as the noble values of national culture that develop in the modern era today. According to Sanjaya, children must get early education to grow and develop based on the educational process carried out by educational institutions in their environment (Sudarsana, Pusparani, Selasih, Juliantari, \& Renawati, 2019). Learning activities will be more effective if the educational process, especially in delivering the material is managed as interesting as possible for students to shape changes in learning behavior so that it is more enjoyable and easily understood by students.

Moving on from educational efforts to produce reliable graduates in the modern era like this, it cannot be separated from teaching methods and the implementation of religious education, because the educational process pursued by students basically aim to develop the knowledge and the potency of students in order to become believers and fear God Almighty, noble, physically and mentally healthy, knowledgeable, capable and skilled, creative, independent, and become a democratic and responsible citizen in accordance with national education goals.

Science is a knowledge about something, while knowledge about education is called education. Educational science is needed to be able to realize the goals of national education, bringing students to have the knowledge and insights needed and have the main personality to meet a better future. Future insightful education is defined as education that can answer the challenges of the future, which is a process that can give birth to intelligent individuals, knowledge, skills, and values needed to live and take part in the era of globalization (Dantes, 2014).

Educational technology is a systematic way of designing, implementing, and evaluating the whole process of learning and learning from a specific form of learning goals, which uses learning resources from humans and things to make learning more effective. In the era of globalization, the advancement of science and technology at the moment is very important where technology provides more teaching role for students to develop the knowledge and skills needed for themselves, society, nation and state.

Educational technology has several roles as a facility to support the construction of knowledge, facility of information, and supporting media to improve the quality of education and improve the effectiveness and efficiency of teaching and learning processes between educators and students. Effectiveness and efficiency are caused by educational technology ranging from the design of the learning process, the translation of design into physical form, as a source of learning, evaluation and assessment of student learning outcomes.

In utilizing technology for educational purposes, it is very helpful and facilitates both teachers and students from various fields to be achieved. Besides technology plays an important role in learning process, it also plays a role in the field of learning evaluation. Learning evaluation is very important in the world of education. Evaluation is used to find out how far the level of students' understanding of the material that has been given during the learning process takes place.

Assessment is an important part of learning. When assessing, teachers managing learning activities can find out the students' ability, the accuracy of the methods used in teaching, and the success of students in achieving the competencies that have been formulated. Based on the results of the assessment, teachers can make decisions correctly to determine the steps which will be taken then. The assessment results can also provide students with motivation to be able to improve their performance. Many types of assessment techniques can be carried out according to the competencies to be assessed. 
The assessment of the learning process is carried out by the teacher as part of teaching the material that has been received by students. It means that assessment must be inseparable in the implementation of teaching. The assessment of the learning process aims to assess the effectiveness and efficiency of teaching activities as material for future improvement and improvement of the program and subsequent teaching implementation. The assessment objectives of the learning process is a part of its own teaching system, including input, process, and output, with all the components in it. The principle of assessment of learning outcomes must meet the following requirements: valid or valid, objective, fair to all, integrated, open, comprehensive and sustainable, systematic, reference criteria, meaningful, and accountable.

To achieve the goals of national education, every school and teacher should be able to develop teaching methods with the right structure at every level of education. Learning that is appropriate with the level of school and student development is a strategy that can be taken by the teacher in learning approach. One of ways that can be conducted is utilizing moodle-based E-Learning in the learning evaluation. Along with the explanation above, the author is interested in describing the implementation of moodlebased e-learning in the learning evaluation.

\section{DISSCUSION}

\subsection{Definition of Moodle-Based E- Learning in Evaluating Learning}

Education is a source of progress for the Indonesian nation, because through education, it will show the competitiveness of a nation in the future which quality must always be improved. The development in Indonesia can only be continued by qualified future generations through intelligent and skilled education or human resources. In the new era of education, reformation related to information systems has emerged. It is very useful for development of science and the world of education itself. There will be a progress in the field of science and technology. When it is used properly and correctly, It will be a component that facilitates its users in life. The concept of utilizing information technology in the world of education is often referred to ELearning

In using E-Learning, many things must be understood from the understanding of e-learning itself, both by teachers and students. Prawiladilaga and Eveline explains that E-Learning or online learning is a learning that must be supported by technological services such as telephone, audio, video, satellite or computer transmission (Prawiladilaga dan Siregar, 2004).

From what has been explained above, it is explained that to apply teaching using the E-Learning system, a school is obliged to provide facilities and infrastructure that support the success of this program. One of the things that must be owned by school are experts or school operators who understand the use of computer programs. Computers are a compulsory means that must be owned by a school, but the more important one is the use of internet and electricity networks that must be prepared to ensure the smooth running of this system (Sanjaya, 2006).

The pattern of using E-Learning is not only utilized in the learning process, but it also used in the educational evaluation, where educators or teachers must evaluate to know the level of students' development and the level of success of the teacher in transferring or giving students an understanding of the material being taught. Evaluation will also make it easier for the teacher to know the level of ability and intelligence of students in understanding the material and the actions that must be done next to improve students' abilities.

The use of E-Learning in the learning evaluation process is now widely applied and utilized by educational 
institutions. One of the uses of ELearning in student learning evaluation is Moodle combined with the use of ExamVeiew.

ExamView is one of the educational technologies that was recently used by teachers / lecturers to make quiz questions (off-line) before being uploaded to moodle. We will experience difficulties when making quiz questions directly in Moodle. Moodle does not have any facilities to make quiz that require special symbols. One of solutions is creating questions using the help of ExamView 6.1.1 software. This software is very easy to install, free and easy to use.

Sukari explains that moodle is an open source and web-based course management software. Moodle is also often referred to as the Course Management System which is currently widely used by various agencies (Sukari, 2013). Currently Moodle has been used by many educational organizations, in providing online education services as an additional delivery channel for education. Moodle can be accessed and downloaded for free via the Wet.

Moodle stands for Modular ObjectOriented Dynamic Learning Environment. (M stands for "Martin's", which refers to Martin Dougiamas, who is the original developer name). The name was chosen because of the dictionary definition from Moodle and to match the available domain name.

\subsection{Strengths and Weaknesses of Moodle- Based E-Learning in Evaluating Learning \\ The utilization of Moodle as one of} the technologies used in carrying out learning evaluations is very important. In facilitating to teach students, teachers must have a fairly mature preparation in the field of skills in understanding the use of Moodle which in essence has several disadvantages and advantages that must be known by the students and teachers.

In using moodle, the facility and infrastructure at schools must support in order to the learning evaluation run well. There are many supporting factors that must be available, including adequate computer facilities, smooth internet network, electricity, and most importantly, operators who can master or understand the operation of this moodle. From these supporting facilities, usually there are obstacles faced in conducting the learning evaluation in using Moodle, so that it needs very thorough preparation from schools, teachers, and students to minimize problems that may occur.

These are some of the weaknesses and requirements of using moodle for student learning evaluations that must be anticipated by the school teachers and students:

a. School must have a computer that is adequate for students to use, so it must have sufficient funds to provide computer facilities.

b. Schools must have educators who are experts in the field of computer, so this program can run well.

c. There must be an adequate electrical installation, because the use of this computer requires an adequate electricity supply and if there is a blackout, the school must provide a backup power supply machine.

d. A good internet network must be owned by the school to facilitate the evaluation process, because often the internet network in rural areas is limited.

e. The teacher must prepare the questions first and enter them in the Exam Vew.

f. The students' ability is not the same in using computer.

g. The time needed to accomplish the questions in Moodle is limited. 
These are the advantages or benefits of Moodle

a. For student

1) Students can learn how to use computers, and train students' abilities.

2) Students are more disciplined to learn, because the use of moodle is limited by the time and questions that the computer scrambles.

3) Students can use Moodle's evaluation as a means of training skills, so when taking UNBK (Computer-Based National Exam) they are used to using computers.

b. For teacher

1) It can minimize the occurrence of cheating because the questions that will appear are randomized by the computer, so that the appearance of the questions will appear differently for each student.

2) The teacher can know the students' score directly after the evaluation process is done because it will immediately appear.

\section{Conclusion}

E-Learning or online learning is a learning which implementation must be supported by technology services such as telephone, audio, video, satellite or computer transmission. Moodle is an open source and web-based course management software. Moodle is also often referred to as the Course Management System which is currently widely used by various agencies. Moodle is often used in the students' learning evaluation process.

The disadvantage of using Moodle is that not all teachers understanding how to evaluate using Moodle. Because of the limitations of the tools in each different regions, not all students understand easily the use of computers, so they need a lot of practice to support the implementation of learning evaluations. The teachers must have knowledge in using Moodle. Moodle as one of the technology utilizationss in terms of learning evaluation, it can also be used as a learning tool for students to train students' skills in computer use and support them to be better trained in dealing with UNBK (Computer-Based National Exams). Another benefit obtained when using moodle is reducing the occurrence of cheating because students are in front of the computer, so there is no chances to cheat. Thus, the students are expected that after taking the exam they get a real score accordance with their ability.

Besides in learning process, technology is very helpful in providing objectives and transparent assessment of student learning outcomes. If technology is used properly, it can help people to make life easier.

\section{REFERENCES}

Dantes, N. (2014). Landasan Pendidikan. Singaraja: Graha Ilmu

Prawiladilaga, D. S. dan Siregar, E. (2004). Mozaik Teknologi Pendidikan. Jakarta:Kencana

Sanjaya, W. (2006). Strategi Pembelajaran. Jakarta: Kencana Prenada Media Grup

Sudarsana, I. K., Pusparani, K., Selasih, N. N., Juliantari, N. K., \& Renawati, P. W. (2019, March). Expectations and challenges of using technology in education. In Journal of Physics: Conference Series (Vol. 1175, No. 1, p. 012160). IOP Publishing.

Sudarsana, I. K., Renawati, P. W., Nerta, I. W., Widana, I. K. A., Saddhono, K., \& Napitupulu, D. (2018, November). The Effectiveness Of Multimedia Training For Elementary School Teachers In Karangasem, Bali. In Journal of Physics: Conference Series (Vol. 1114, No. 1, p. 012032). IOP Publishing.

Sukari. (2013). "Mengembangkan eLearning Sekolah". Jakarta: Esensi Erlangga Grup.

Triyana, I. G. N. (2017). Penjaminan Mutu Pendidikan Melalui Teknologi Informasi Di Institut Hindu Dharma Negeri Denpasar. Jurnal Penjaminan Mutu, 3(1), 119-126. 